\author{
Alexandre Normandeau, Gabriel Joyal, Patrick Lajeunesse,

\begin{abstract}
East Lake, located at Cape Bounty (Melville Island, Canadian High 7 Arctic), was mapped using a high-resolution swath bathymetric sonar and a 8 $12 \mathrm{kHz}$ sub-bottom profiler, allowing for the first time the imaging of widespread 9 occurrence of mass movement deposits (MMDs) in a Canadian High Arctic Lake. 10 Mass movements occurred mostly on steep slopes away from deltaic sedimentation. 11 The marine to lacustrine transition in the sediment favours the generation of mass 12 movements where the underlying massive mud appears to act as a gliding surface 13 for the overlying varved deposits. Based on acoustic stratigraphy, we have identi- 14 fied at least two distinct events that triggered failures in the lake during the last 15 2000 years. The synchronicity of multiple failures and their widespread distribution 16 suggest a seismic origin that could be related to the nearby Gustaf-Lougheed Arch 17 seismic zone. Further sedimentological investigations on the MMDs are however 18 required to confirm their age and origin.

\title{
31.1 Introduction
}

Sediment archives from Arctic lakes are commonly used for paleoenvironmental 22 and paleoclimatic reconstructions (e.g., Lapointe et al. 2012). Lake basins in the 23 Arctic can accumulate large amounts of sediment derived from landscape runoff 24

\footnotetext{
A. Normandeau $(\bowtie) \cdot$ G. Joyal $\bullet$ P. Lajeunesse

Centre d'études nordiques, GEOTOP and Département de Géographie, Université Laval,

Québec, QC, Canada G1V 0A6

P. Francus $\bullet$ F. Lapointe

Institut national de la recherche scientifique, Centre Eau-Terre-Environnement, Québec, QC,

Canada G1K 9A9

GEOTOP, City, Country
}

S. Lamoureux

Department of Geography, Queen's University, Kingston, ON, Canada K7L 3N6 
and in some cases preserve varves (e.g., Lapointe et al. 2012). Because this polar region is highly sensitive to climate change via feedback processes, high-resolution sedimentary records are particularly beneficial for assessing natural climate variability and for validating climate models (Kaufman 2009). However, an increasing number of studies demonstrate that lacustrine sedimentation is also influenced by mass movements, which can be unrelated to climate variability (e.g., Beck 2009; Waldmann et al. 2011). Understanding sedimentary processes within lakes is thus of major interest for interpreting past climate and predicting future climatic change. Studying such processes in Arctic lakes is challenging because they are often inaccessible with an ice cover for up to 10 months per year. Further, lake studies in the High Arctic rely solely on the interpretation of sediment cores while the geological, stratigraphic and geomorphological context in which sediment deposition takes place are often left undocumented.

In this paper, we report and describe for the first time sub-lacustrine landslides and sedimentary processes that occurred in a Canadian High Arctic Lake (East Lake, Cape Bounty) from the analysis of high-resolution swath bathymetry and sub-bottom profiling. This paper also aims at documenting pre-conditioning factors and the approximate timing of mass movement deposits in order to identify possible triggers for extreme events recorded in previously analyzed sedimentary records from the lake (Cuven et al. 2011; Lapointe et al. 2012).

\subsection{Regional Setting}

East Lake (unofficial name, $74^{\circ} 53^{\prime} \mathrm{N}, 109^{\circ} 32^{\prime} \mathrm{W}$ ) is located on the south-central coast of Melville Island, in the western Canadian Arctic Archipelago (Fig. 31.1a). It is a small-sized and $\sim 30-\mathrm{m}$ deep lake $(1 \times 2 \mathrm{~km})$ located $5 \mathrm{~m}$ above sea-level (asl; Fig. 31.1b). The area was entirely covered by the Laurentide Ice Sheet (LIS) during the Late-Wisconsinan (Nixon et al. 2013). By $14 \mathrm{ka}$ cal BP, the retreat of the LIS margin led to the marine invasion, which reached areas today located at $\sim 75 \mathrm{~m}$ asl. Following emergence from the sea due to glacio-isostatic rebound, an estuary and then a lake formed by $2195 \mathrm{BC}$ and $243 \mathrm{AD}$ respectively, providing a favorable environment for varve formation (Cuven et al. 2011).

The watershed of East Lake (and the adjacent West Lake) has been monitored since 2003 for hydrological, limnological and sediment transport and deposition studies, making it the longest comprehensive hydrological-limnological monitoring program in the Canadian High Arctic. E.g., Cuven et al. (2011) and Lapointe et al. (2012) have linked hydroclimatic variability to the physical and geochemical properties of the varves. Lapointe et al. (2012) documented a recent increase in rainfall events since 1920, with unprecedented levels occurring late in the twentieth century that are likely linked with the ongoing warming in the Arctic.

Cape Bounty is located $\sim 150-200 \mathrm{~km}$ south-west from the Gustaf-Lougheed Arch Seismic Zone (GLASZ) (Fig. 31.1a). An earthquake swarm (65 locatable 


\section{Author's Proof}

31 Late-olocene Mass Movements in High Arctic East Lake, Melville Island...

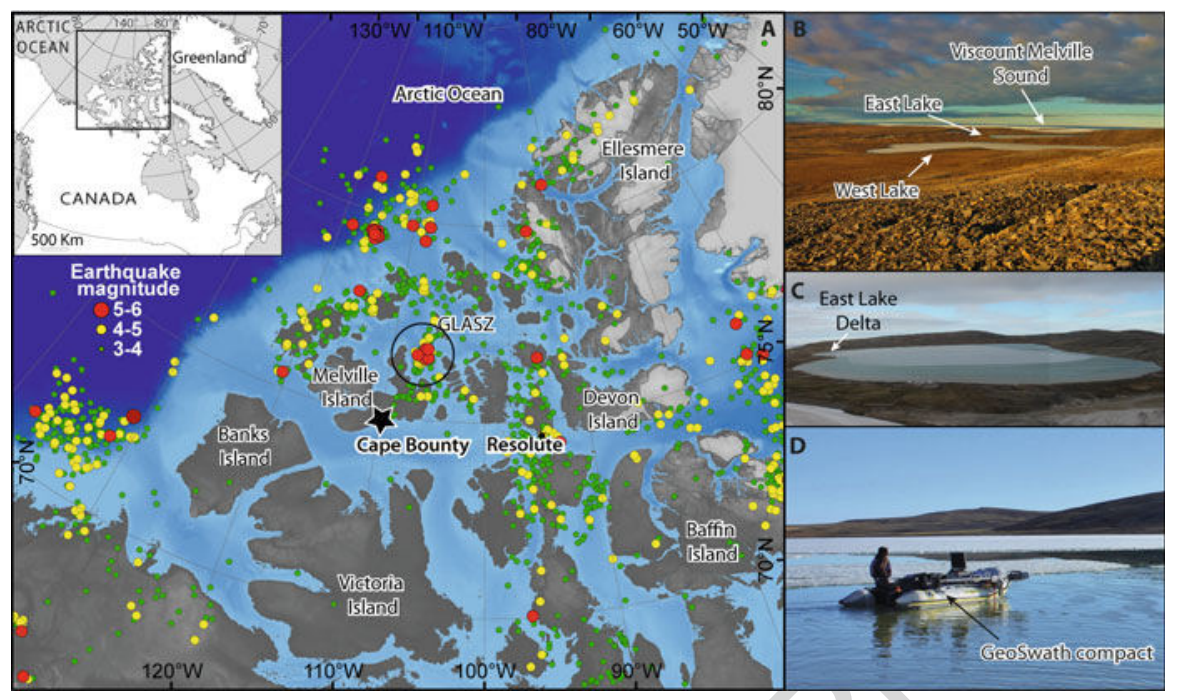

Fig. 31.1 (a) Location of Cape Bounty (Melville Island, Canadian High Arctic) and of recent earthquakes (GLASZ = Gustaf-Lougheed Arch Seismic Zone); (b) Overview of East and West Lake in early August 2013; (c) View of East Lake and its delta. Note the presence of ice, which limited the coverage of the hydroacoustic surveys over the entire lake; (d) GeoAcoustics GeoSwath echosounder mounted on an inflatable boat on East Lake

earthquakes in 55 days) with four major $(M>5)$ earthquakes occurred in the region 65 during November-December 1972 (Hasegawa 1977). An earthquake of M 5.6 also 66 occurred in 2001 .

\subsection{Methods}

A high-resolution bathymetric map of East Lake was produced from a 69 hydroacoustic survey undertaken in 2013. A GeoAcoustics GeoSwath Plus compact 70 interferometric bathymetric sonar $(250 \mathrm{kHz})$ was deployed on a $2.5 \mathrm{~m}$ inflatable 71 boat (Fig. 31.1d). A total of $12.5 \mathrm{~km}$ of subsurface data was acquired on the 72 northern half of the lake using a $12 \mathrm{kHz}$ Knudsen 3212 echosounder from the 73 same boat and interpreted using The Kingdom Suite ${ }^{\circledR}$ and SonarWiz $5.0 \AA$ soft- 74 wares. Due to the presence of residual lake ice during the survey in early August 75 2013 (Figs. 31.1c, d), swath bathymetry data was collected over $75 \%$ of the lake 76 while sub-bottom profiles were collected only over the northern half of the lake 77 area. The survey capabilities were highly dependent on daily wind directions which 78 pushed the seasonal lake-ice cover from one end of the lake to the other. 


\section{Author's Proof}

A. Normandeau et al.

80

81

82

83

84

\subsection{Results}

\subsubsection{High-Resolution Bathymetry}

East Lake forms a $30 \mathrm{~m}$-deep overall round basin. The greatest depths are located in the central part of the lake, near the East River delta (Fig. 31.2). The slopes are steep on all sides of the basin, reaching $\geq 10^{\circ}$ (Fig. 31.3a). The slopes are especially steep

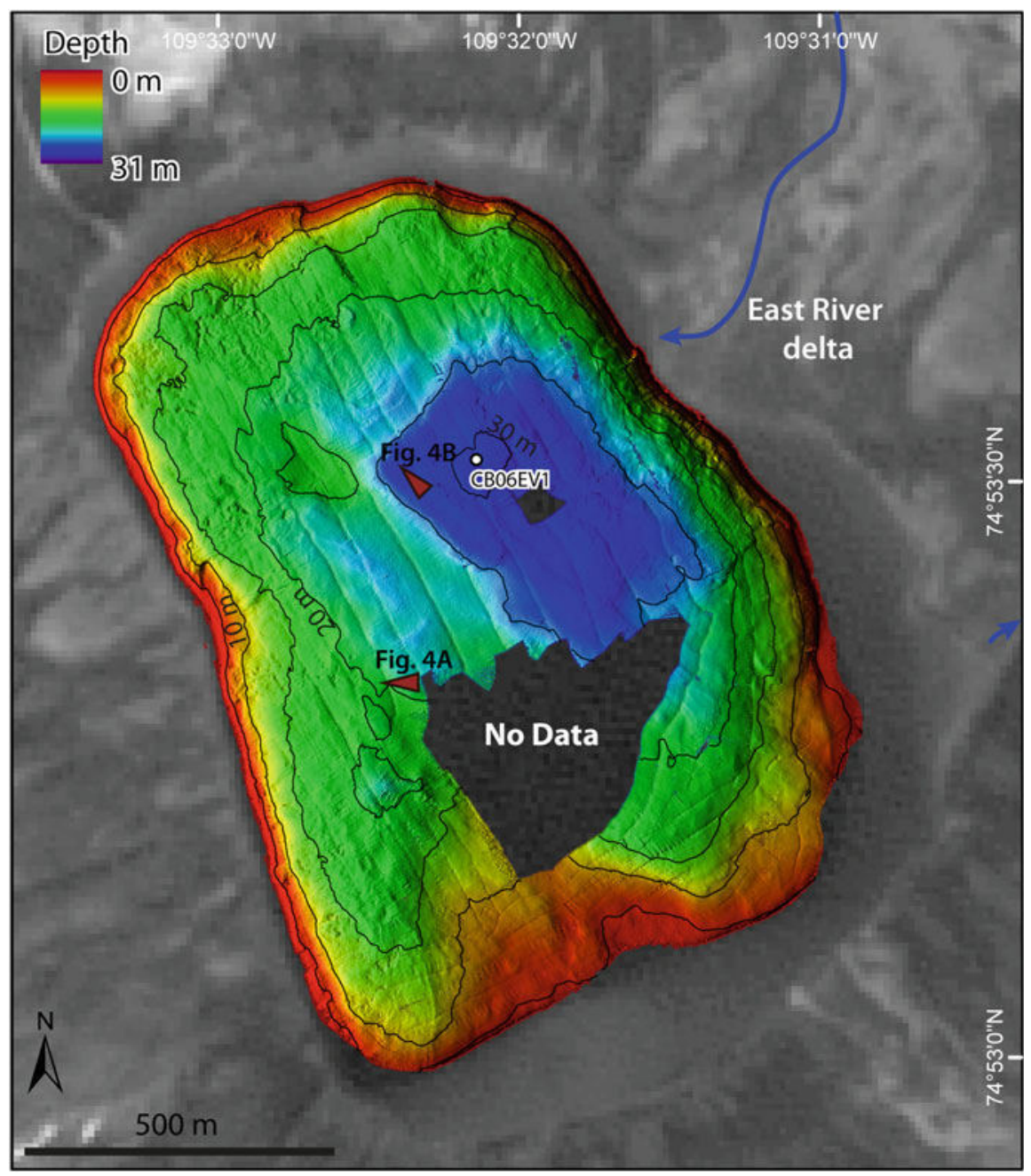

Fig. 31.2 Swath bathymetry map of East Lake (Cape Bounty, Melville Island). Regions of no data are due to the presence of ice during the 2013 survey. Red arrows indicate the viewpoints of Fig. 31.4 


\section{Author's Proof}

31 Late-olocene Mass Movements in High Arctic East Lake, Melville Island...

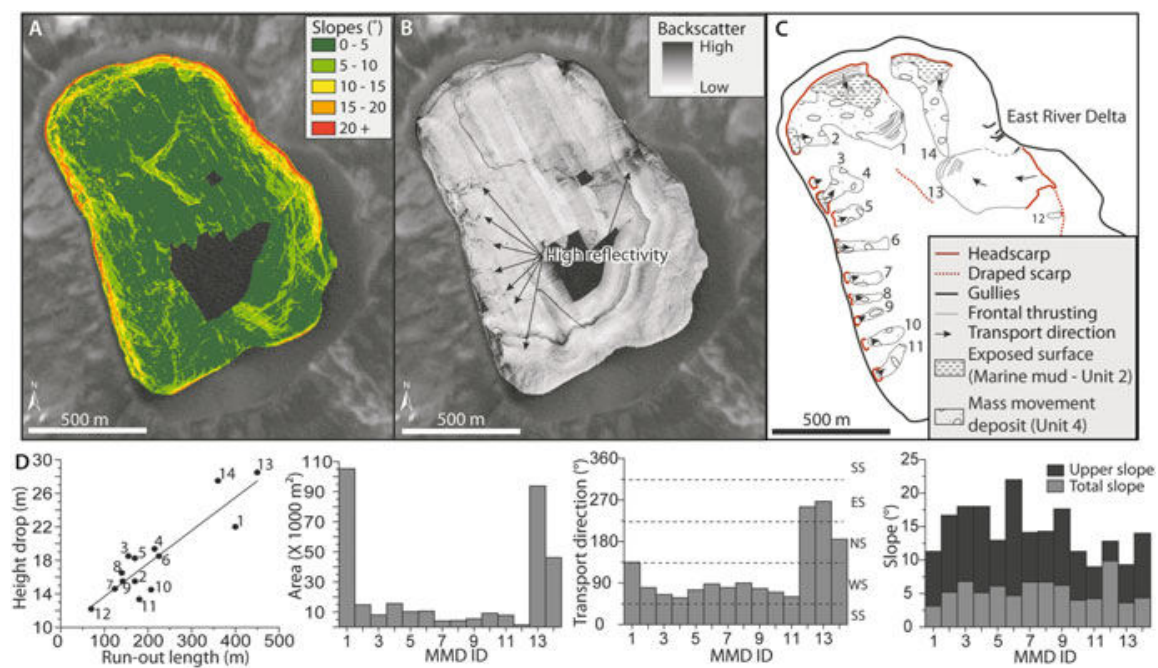

Fig. 31.3 Morphological characteristics of East Lake mass movements: (a) Slope map; (b) Reflectivity map; (c) Geomorphological map of mass movement's morphologies of the lake floor; (d) Morphological properties of 14 mass movements identified in (c)

on the eastern, northern and western margins of the lake, where they occasionally 85 reach $\geq 15^{\circ}$. The southern portion has a gentle slope that rarely reaches $\geq 5^{\circ}$. 86

Two main types of lake-floor morphologies are observed in the lake: (1) gullies 87 at the delta front; and (2) mass movement deposits (MMDs) throughout the lake, 88 mostly on the northern and western slopes (Fig. 31.3c). Erosional gullies are $\sim 50 \mathrm{~m} 89$ long and less than $10 \mathrm{~m}$ wide and are located at the mouth of the East River 90 (Fig. 31.2). Fourteen MMDs were identified from surface morphology alone 91 (Fig. 31.3c). The sizes of the MMDs vary along the slopes of the lake, but most 92 have height drops of 14-20 m and run-out distances of 150-250 m. Three MMDs 93 are much larger (No. 1, 13, 14; Fig. 31.3c), with run-out distances and height drops 94 of $>350 \mathrm{~m}$ and $>22 \mathrm{~m}$, respectively (Figs. $31.3 \mathrm{c}, \mathrm{d}$ ). The scar gradient of each 95 MMD is generally $\geq 10^{\circ}$. The mean area of the deposits is $10,000 \mathrm{~m}^{2}$, excluding the 96 two largest that are $\sim 100,000 \mathrm{~m}^{2}$. One of the two largest MMDs is found near the 97 delta front, and the other one on the northern slope. Compressional ridges are 98 located at the front of these two larger MMDs while extensional ridges are observed 99 near the headscarp of the northernmost MMD (Fig. 31.4b). The smaller MMDs 100 consist mainly of boulder-size debris (Fig. 31.4a).

The backscatter map reveals a general low-intensity backscatter of the lake floor 102 (Fig. 31.3b). This low intensity is interpreted to represent the undisturbed and 103 normally deposited lacustrine sediment. The highest intensities observed along 104 the western slope of the lake floor illustrate the debris nature of the MMDs 105 (Figs. 31.3b and 31.4a). The lowest intensities are observed on the northern and 106 southern parts of the lake, where mass movements cannot be identified from 107 


\section{Author's Proof}

A. Normandeau et al.

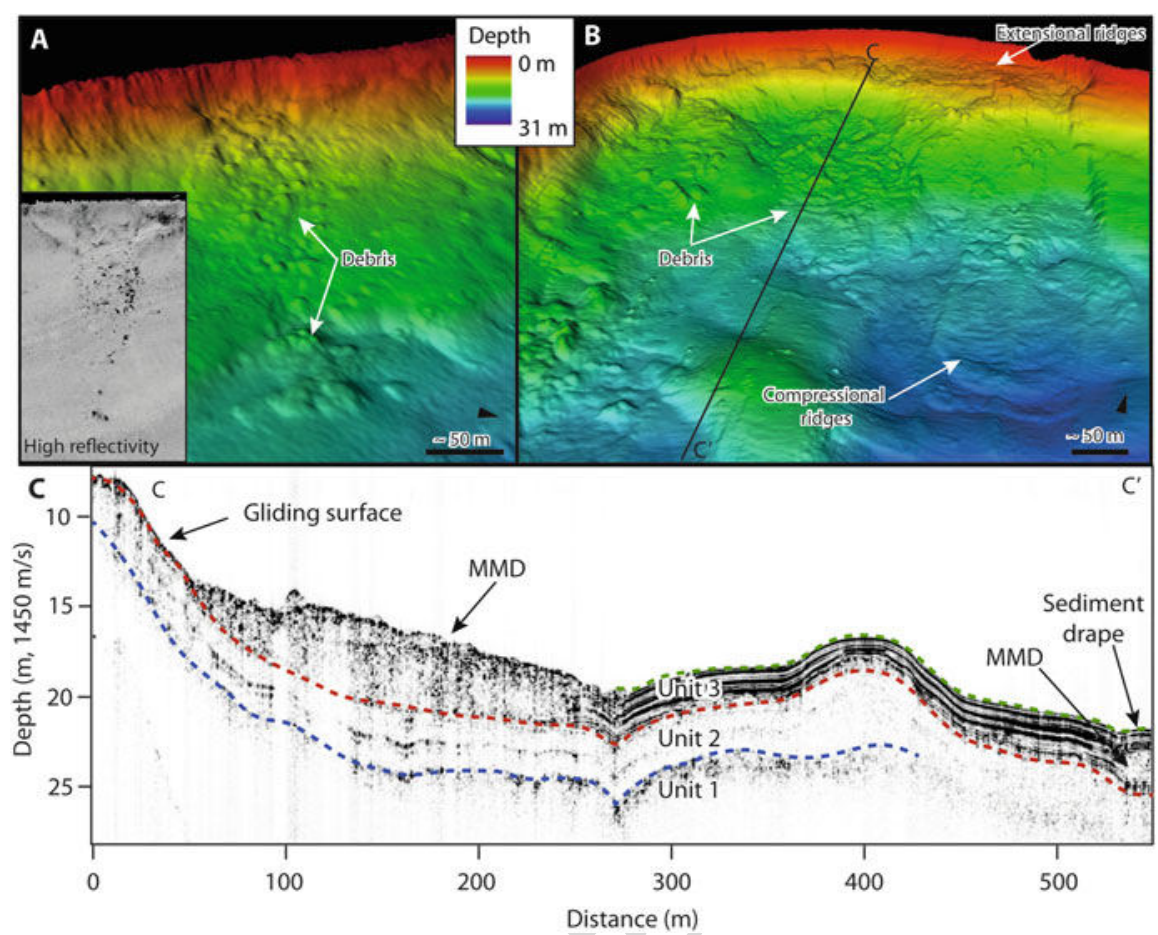

Fig. 31.4 3D view of mass movements 6 (a) and 1 (b) identified in East Lake. Location of images is provided in Fig. 31.2; (c) Sub-bottom profile illustrating the three acoustic units and MMDs. Location of profile provided in (b)

backscatter intensities. The delta front is also characterized by higher intensities, reflecting the coarser nature of the sediment discharged from the East River.

\subsubsection{Acoustic Stratigraphy}

Three acoustic stratigraphic units were identified in East Lake (Figs. 31.4c and 31.5). Lowermost Unit 1 is characterized by an absence of penetration and represents the acoustic basement. Unit 2 overlies Unit 1 and is acoustically transparent with few low-amplitude reflections. It appears to be present throughout the lake. Based on the depth of this unit from the lake bottom $(\leq 4 \mathrm{~m})$, its uppermost part appears to have been reached by a $7 \mathrm{~m}$-long core (Cuven et al. 2011) and represents massive compacted mud, interpreted as marine sediments deposited prior to the lacustrine phase $\geq 4 \mathrm{ka} \mathrm{BP}$. Unit 3 consists of high-amplitude reflections and drapes the underlying units. It was previously cored and consists of annually deposited silt and sand rythmites (varves) (Cuven et al. 2011; Lapointe et al. 2012). 


\section{Author's Proof}

31 Late-olocene Mass Movements in High Arctic East Lake, Melville Island...

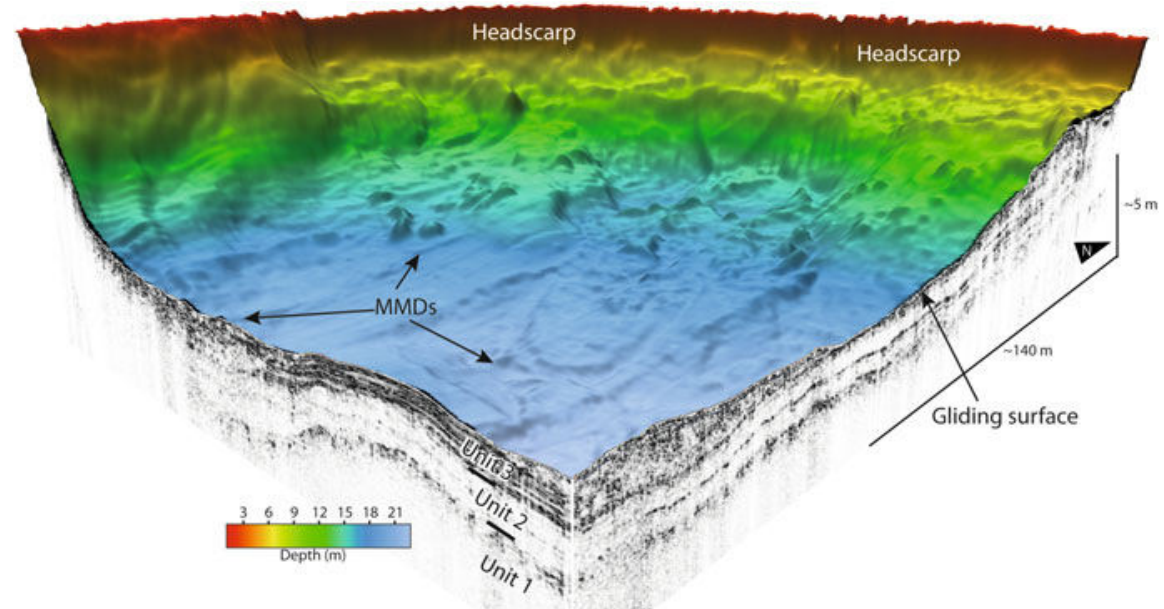

Fig. 31.5 3D view of swath bathymetry on sub-bottom profiles illustrating units $1-3$ present in East Lake

Unit 3, however, is not present throughout the entire lake subsurface (Figs. 31.4c and 31.5). It is absent on steep sub-lacustrine slopes but can reach $4 \mathrm{~m}$ in thickness in the deepest part of the lake. At the top or within Unit 3, transparent to chaotic bodies (Fig. 31.4c) are interpreted as localized MMDs and are mostly observed at the base of steep slopes. The massive mud of Unit 2 is often exposed where the mass movements eroded the overlying Unit 3 (Figs. 31.4c and 31.5), illustrating that this unit probably acts as a gliding surface for MMDs.

\subsection{Discussion}

\subsubsection{Factors Pre-conditioning Failures}

High-resolution bathymetric data and sub-bottom profiles collected in East Lake 130 show widespread evidence of MMDs. These MMDs are mostly located on steep 131 slopes of the western and northern sectors of the lake. On the eastern side, steep 132 slopes are also observed but gullies indicate that turbidity currents erode the lake 133 floor, particularly at the delta front. Sub-bottom profiles reveal that the varved 134 sediments (Unit 3) slid over the underlying massive mud (Unit 2), suggesting a 135 stratigraphic control in the generation of MMDs where the top of Unit 2 acts as a 136 gliding surface for the overlying silty-to-sandy laminated sediments. This abrupt 137 change in type of sediment (e.g., marine to lacustrine) reduces slope stability and 138 favours development of a weak layer or weak interface that subsequently can lead 139 


\subsubsection{Recent Sediment Failures}

The number of individual events responsible for the occurrence of MMDs in East Lake is difficult to quantify due to the absence of sediment cores associated with each mass movement. Based on the available sub-bottom profiles, at least two different episodes of sediment failures appear to have occurred during the last $\sim 2000$ years. $\sim 1 \mathrm{~m}$ of varved sediment covers two MMDs, one of them visible on Fig. 31.4c. Moreover, core CB06EV1 (Fig. 31.2) has a prominent coarse layer at a depth of $1.3 \mathrm{~m}$ that was deposited at $1300 \mathrm{AD}$ (Lapointe et al. 2012). This coarse layer (turbidite?) is probably the distal result of the lowermost MMD located on the eastern margin (MMD 13) thus suggesting a date of $~ 1300$ AD for this first mass movement episode (Lapointe et al. 2012).

Core CB06EV1 recorded many coarse layers and turbidites, which suggests an influence from river floods in the accumulation of sediments in the lake (Lapointe et al. 2012). The presence of gullies reveals the occurrence of turbidity currents that could have been triggered by flood discharge and associated high suspended sediment loads. Hyperpycnal currents are frequent in freshwaters (e.g., Simonneau et al. 2013) and occur in East Lake since suspended sediment concentrations are especially high during snowmelt (Cockburn and Lamoureux 2008). Presently, the differentiation between river-generated turbidites (flood event layers) and mass movement induced turbidites has not been accomplished because previous studies in East Lake have not identified the distinct sedimentological signature of both deposits.

Thirteen other MMDs appear to have a similar and more recent age since they are located in the upper acoustic stratigraphy sequence (Fig. 31.4c). One of the largest turbidites analyzed in previous studies in the lake was dated with varves, ${ }^{210} \mathrm{~Pb}$ and ${ }^{137} \mathrm{Cs}$ dating at $1972-1973 \mathrm{AD}$ by Cuven et al. (2011) and at $1971 \mathrm{AD}$ by Lapointe et al. (2012). This turbidite could be related to hyperpycnal flows but we rather interpret it as the distal result of a mass movement that reached the deeper basin (e.g., MMD 1 and/or 14). Based on this interpretation, the second mass movement event observed in the lake could have been triggered between 1971 and 1973.

The synchronicity of multiple MMDs and their widespread distribution in the lake suggest that mass movements were triggered by seismicity. An earthquake swarm occurred in the GLASZ during November-December 1972, the strongest event reaching M 5.7, at a focal depth of 9-14 km (Fig. 31.1a) (Hasegawa 1977). The distance of the earthquakes $(200 \mathrm{~km})$ would attenuate the intensity felt at East Lake. However, accepting Cuven et al. (2011) core chronology, the recent MMDs and the turbidite observed in core $\mathrm{CB} 06 \mathrm{EV} 1$ could be related to seismic activity in 


\section{Author's Proof}

31 Late-olocene Mass Movements in High Arctic East Lake, Melville Island...

the GLASZ since it is dated to the winter of 1972-1973. This hypothesis is also 182 supported by the presence of the MMDs on the northern slope, far from the East 183 River inflow where sediment loading would be minimal. Earthquake shaking causes 184 significant strength reduction in stratified sediments (Cauchon-Voyer et al. 2008) 185 and could have caused slipping over Unit 2 and the failure of the steep lake margins. 186 However, more sediment cores are needed to constrain the chronology of MMDs in 187 East Lake and infer their exact triggers through time.

\subsection{Conclusion}

Our survey in East Lake allowed for the first time the imaging of sediment 190 instabilities in a Canadian High Arctic Lake. These results show that mass move- 191 ments are ubiquitous in East Lake (Melville Island) and that their deposits cover a 192 large part of the lake floor. Data suggest that steep slopes and the stratified package 193 of lacustrine sediments on top of compacted marine deposits are favouring factors 194 for the development of MMDs. Swath bathymetry and acoustic stratigraphy indi- 195 cates that at least two different mass movement events occurred during the last 196 2000 years. A tentative timing for the events is proposed based on previous 197 sediment core analysis (Cuven et al 2011; Lapointe et al. 2012) and acoustic 198 stratigraphy. A first event appears to have occurred near 1300 AD while more 199 recent events are tentatively dated to 1970-1973 based on a prominent turbidite 200 present in a core record. These recent MMDs could be related to an earthquake 201 swarm that occurred in the GLASZ in the winter of 1972. Collection of cores from 202 MMDs will lead to a better dating of the events and allow reconstructing Holocene 203 paleo-seismicity or environmental change leading to sediment failures in this High 204 Arctic Lake. Although the exact processes responsible for MMDs in East Lake are 205 not adequately explained for the moment, we have demonstrated that the interpre- 206 tation of sediment cores from high-latitude lacustrine environments for paleo- 207 environmental reconstructions needs to be supported by a high-resolution analysis 208 of the geomorphology and stratigraphy of the lake floor.

Acknowledgements This study was supported by NSERC through Discovery grants to P.L., P.F., 210 and S.L., NSERC Northern supplement grants to P.F., the Canadian Foundation for Innovation and 211 the Ministère de l'Éducation du Québec through equipment grants to P.L., and the Polar Conti- 212 nental Shelf Program through grants to P.F. and S.L. Flavio Anselmetti, Marc DeBatist and Editor 213 Sebastian Krastel provided helpful comments that improved the quality of this paper.

\section{References}

Baeten NJ, Laberg JS, Vanneste M, Forsberg CF, Kvalstad TJ, Forwick M, Vorren TO, Haflidason 216 $\mathrm{H}$ (2014) Origin of shallow submarine mass movements and their glide planes - sedimento- 217 logical and geotechnical analyses from the continental slope off northern Norway. J Geophys 218 Res Earth Surf 119:2335-2360 


\section{Author's Proof}

A. Normandeau et al.

Beck C (2009) Late-Quaternary lacustrine paleo-seismic archives in north-western Alps: examples of earthquake-origin assessment of sedimentary disturbances. Earth Sci Rev 96:327-344

Cauchon-Voyer G, Locat J, St-Onge G (2008) Late-Quaternary morpho-sedimentology and submarine mass movements of the Betsiamites area, Lower St. Lawrence Estuary, Quebec, Canada. Mar Geol 251:233-252

Cockburn JMH, Lamoureux SF (2008) Hydroclimate controls over seasonal sediment yield in two adjacent high Arctic watersheds. Hydrol Process 22:2013-2027

Cuven S, Francus P, Lamoureux S (2011) Mid to Late Holocene hydroclimatic and geochemical records from the varved sediments of East Lake, Cape Bounty, Canadian High Arctic. Quat Sci Rev 30:2651-2665

Hasegawa HS (1977) Focal parameters of four Sverdrup Basin, Arctic Canada, earthquakes in November and December of 1972. Can J Earth Sci 14:2481-2494

Kaufman DS (2009) An overview of late Holocene climate and environmental change inferred from Arctic lake sediment. J Paleolimnol 41:1-6

Lapointe F, Francus P, Lamoureux SF, Saïd M, Cuven S (2012) 1750 years of large rainfall events inferred from particle size at East Lake, Cape Bounty, Melville Island, Canada. J Paleolimnol 48:159-173

Nixon FC, England JH, Lajeunesse P, Hanson MA (2013) Deciphering patterns of postglacial sea level at the junction of the Laurentide and Innuitian Ice Sheets, western Canadian High Arctic. Quat Sci Rev 91:165-183

Simonneau A, Chapron E, Vannière B, Wirth SB, Gilli A, Di Giovanni C, Anselmetti FS, Desmet M, Magny M (2013) Mass-movement and flood-induced deposits in Lake Ledro, southern Alps, Italy: implications for Holocene palaeohydrology and natural hazards. Clim Past 9:825-840

Strasser M, Stegmann S, Bussmann F, Anselmetti FS, Rick B, Kopf A (2007) Quantifying subaqueous slope stability during seismic shaking: lake Lucerne as model for ocean margins. Mar Geol 240:77-97

Waldmann N, Anselmetti FS, Ariztegui D, Austin JA Jr, Pirouz M, Moy CM, Dunbar R (2011) Holocene mass-wasting events in Lago Fagnano, Tierra del Fuego $\left(54^{\circ} \mathrm{S}\right)$ : implications for paleoseismicity of the Magallanes-Fagnano transform fault. Basin Res 23:171-190 